\title{
Effects of taxes on youth self-employment and income
}

\author{
Johan Egebark
}


The Institute for Evaluation of Labour Market and Education Policy (IFAU) is a research institute under the Swedish Ministry of Employment, situated in Uppsala. IFAU's objective is to promote, support and carry out scientific evaluations. The assignment includes: the effects of labour market and educational policies, studies of the functioning of the labour market and the labour market effects of social insurance policies. IFAU shall also disseminate its results so that they become accessible to different interested parties in Sweden and abroad.

IFAU also provides funding for research projects within its areas of interest. The deadline for applications is October 1 each year. Since the researchers at IFAU are mainly economists, researchers from other disciplines are encouraged to apply for funding.

IFAU is run by a Director-General. The institute has a scientific council, consisting of a chairman, the Director-General and five other members. Among other things, the scientific council proposes a decision for the allocation of research grants. A reference group including representatives for employer organizations and trade unions, as well as the ministries and authorities concerned is also connected to the institute.

Postal address: P.O. Box 513, 75120 Uppsala

Visiting address: Kyrkogårdsgatan 6, Uppsala

Phone: +4618 4717070

Fax: +4618471 7071

ifau@ifau.uu.se

www.ifau.se

Papers published in the Working Paper Series should, according to the IFAU policy, have been discussed at seminars held at IFAU and at least one other academic forum, and have been read by one external and one internal referee. They need not, however, have undergone the standard scrutiny for publication in a scientific journal. The purpose of the Working Paper Series is to provide a factual basis for public policy and the public policy discussion.

ISSN 1651-1166 


\title{
Effects of Taxes on Youth Self-Employment and Income*
}

\author{
Johan Egebark ${ }^{\dagger}$
}

March 1, 2016

\begin{abstract}
I study the link between taxes and youth self-employment. I make use of a Swedish reform, implemented in 2007-09, which suddenly made the payroll tax and the self-employment tax vary by age. The results suggest that youth self-employment is insensitive to tax reductions, both in the short run and in the somewhat longer run. I also study the effect of the tax reductions on income. For those that are defined as self-employed, I find positive effects on income from self-employment, and negative effects on income from wage employment. This finding suggests that the lower taxes caused the self-employed to reallocate time from employment to selfemployment.
\end{abstract}

Key words: Youth unemployment; Self-employment tax; Tax subsidy; Self-employment

JEL classification: H25, H32, J23, J38, J68

*I wish to thank Peter Fredriksson, Helena Holmlund, Niklas Kaunitz, Martin Olsson, Roope Uusitalo, and Jonas Vlachos for valuable comments. Financial support from the Jan Wallander and Tom Hedelius Foundation is gratefully acknowledged. All errors are my own.

${ }^{\dagger}$ Swedish Public Employment Service and Research Institute of Industrial Economics (IFN), Stockholm, Sweden. E-mail: johan.egebark@ifn.se 


\section{Introduction}

High and persistent youth unemployment is a major concern for many developed economies. Different policies have been tested to address this problem. In the 1990's the UK government launched large-scale active labor market programs (the New Deal for the Young and Unemployed) to improve young individuals' labor market opportunities (Blundell et al., 2004). More recently, as a response to the 2008 financial crisis, many countries, including France and Spain, have initiated different types of targeted hiring credits in attempts to boost employment among the young (Cahuc et al., 2014; Ferran, 2015).

High youth unemployment could reflect the fact that young individuals have few options in the formal sector, due to for example their lack of work experience or social connections. This suggests that one way for them to exit unemployment is to start their own business. In fact, means to stimulate self-employment is increasingly seen as part of a strategy to handle the youth employment challenge. The European Commission's Youth Employment Package, launched in 2012, states explicitly that the member states should support job creation by "promoting and supporting self-employment /.../ and business start-ups" and should focus its efforts on "business start-ups by unemployed and people from disadvantaged groups" (European Comission, 2013). One concrete example comes from Spain, where the government recently launched new initiatives to increase self-employment rates among young adults. Measures include lower social contributions and the possibility of extending unemployment benefits for young people that register a business.

Despite the potential role that self-employment could play, there are few studies on how to increase the number of businesses run by young individuals. OECD has suggested two main interventions: entrepreneurship education and financial support. However, since there are basically no (credible) evaluations of the effectiveness of these policies, it is difficult for policymakers to know what approaches actually work (OECD, 2012, 2013). ${ }^{1}$

In this paper, I provide hard evidence of whether reducing taxes is an effective way to increase

\footnotetext{
${ }^{1}$ There are studies on the effects of entrepreneurship education (see, e.g., Oosterbeek et al., 2010). However, these studies do not focus on disadvantaged groups: participants are often college graduates since the evaluated training is part of some higher education. Furthermore, as it is often the participants' intentions that are studied, the findings do not say whether training actually leads to self-employment.
} 
youth self-employment. I make use of a Swedish reform, implemented in two steps during 2007-09, that introduced substantial variation in tax rates across age groups. In July, 2007, the employerpaid payroll tax was cut by 11 percentage points for workers who, at the start of the year, had turned 18 but not 25 years of age. These age groups were, at the same time, allowed a 10 percentage points reduction in the self-employment tax. After 18 months, the initial reduction was modified: both the payroll tax and the self-employment tax was cut additionally, and the target group was extended so that the reductions now encompassed all individuals who at the start of the year had not yet turned 26 years of age. The two reductions suddenly made taxes vary across cohorts, and, hence, offer a good opportunity to study the causal effects of taxation on a young person's decision to run a business.

I use Differences-in-Differences (DiD) to identify the effect of the tax changes, contrasting individuals below the treatment defining age cutoff to those just above. I consider the effects on the (overall) self-employment rate, and on transitions between self-employment and wage employment (i.e., on occupational choice). By studying each of the two reductions separately, I examine whether the effect varies depending on the state of the economy. Furthermore, by using different age intervals I am able to uncover whether the effect varies across ages.

The results suggest that youth self-employment is insensitive to tax changes. Both the 2007 cut and the 2009 cut left self-employment completely unaffected. The lack of treatment effects is precisely estimated and is robust to a battery of sensitivity tests. For example, none of the subgroups that I consider - e.g., men, women, natives, foreign-born, or those with vocational training - display any effects. The fact that there was no impact in 2009-10, i.e. in the midst of recession, suggests that (large) tax cuts have no role to play even in times of economic slowdowns.

I proceed by looking at intensive margin responses. I first show that for the young self-employed that faced the lower tax rate - essentially because they were lucky - income from self-employment increased by up to 20 percent on average. I then compare the estimated income effect to the predicted mechanical effect (due to the lower tax rate) and find that, in each year 2007-09, the estimated effect is greater. ${ }^{2}$ I argue that a potential explanation for this pattern is that the tax

\footnotetext{
${ }^{2}$ The mechanical effect is the positive effect that exists irrespective of behavioral adjustments (Chetty et al., 2013).
} 
cut caused self-employed individuals to allocate more time to self-employment - either by reducing time in leisure or in wage employment. I find some support for the reallocation of time explanation: for those that are defined as self-employed, income from regular employment decreases due to the tax cut. Since the income effect is temporary, however, I conclude that the reallocation of working hours did not pertain to years when an individual no longer faces the lower tax rate. While intensive margin responses to tax changes have proven difficult to detect in the past, recent work shows that such adjustments can be substantial (Chetty et al., 2013).

The rest of the paper is organized as follows. Sections 2 and 3 offer some background. Section 4 briefly describes the conceptual framework. Sections 5 and 6 handle the data and the identification strategy. Section 7 gives the results and section 8 concludes.

\section{Institutional framework}

\subsection{Youth unemployment in Sweden}

Official records show that youth unemployment in Sweden is currently high. Unemployment for 15-25 year-olds was roughly at 24 percent in 2013, which is three times higher than overall unemployment (Statistics Sweden, 2014). In 2007 and 2008, which are the years that I mainly focus on in this study, youth unemployment was somewhat lower, at around 20 percent. In 2009, when the Swedish economy was fully hit by the financial crisis, it increased to 25 percent.

It is sometimes argued that these (official) figures exaggerate the problem of youth unemployment in Sweden, mainly due to the fact that a large number of the unemployed participate in different types of education. Excluding those who study full-time lowers unemployment for 15-25 year-olds to about 12 percent in 2013. However, it is not obvious that this adjustment makes sense: many might chose to study since it is difficult to find a job, even though they rather would be working.

I complement these figures with two other measures to provide some further understanding of the problem in the Swedish case. First, about 10 percent of all 20-24 year-olds were not employed and not in any education or training in 2013 (i.e., they belong to the so called NEET category). In 
2007-08, the corresponding figure was 12 percent, and in 2009 it was roughly 13 percent (Statistics Sweden, 2014). A second measure looks at registrations at the unemployment office. The data that I use for the analysis below contains yearly information on job search activity, and so I can observe those that are registered as looking for a job. 21 percent of all 20-24 year-olds were registered at the unemployment office at some point during 2007-08, and 8 percent were registered for more than 100 days. During the recession year 2009, these figures increased to 24 percent and 12 percent, respectively.

\subsection{The 2007-09 tax reductions}

Swedish employers finance welfare services for employees, such as pensions and health and disability insurances, through payroll taxes. Payroll taxes are proportional to the employee's wage bill, and consist of seven mandatory fees. Those who are self-employed finance their own welfare through a mandatory self-employment tax. This is essentially a tax on the surplus that the business has generated during the year. Between 2007 and 2009, the payroll tax for employers of young workers was cut in two steps. During the same period, young business owners were twice allowed reductions in the self-employment tax. Figures 1 (a) and 1 (b) provide a graphical illustration of these reductions.

On July 1, 2007, the payroll tax was cut by roughly 11 percentage points for (employers of) workers who, at the start of the year, had turned 18 but not 25 years of age. Six out of seven mandatory fees were halved, reducing the tax rate from 32.42 to 21.32 percent. Individuals within the same age interval were, from the same date, allowed a reduction in the self-employment tax. The rate was cut by 10 percentage points from 30.71 to 20.45 percent. ${ }^{3}$ On January 1, 2009, the reform was modified in two ways. First, the target group was extended at both ends so that the reductions now encompassed all individuals who at the start of the year had not yet turned 26 years of age (i.e., the upper cutoff was changed and the lower cutoff was abolished). Second, the payroll tax was lowered additionally to 15.52 percent, and the self-employment tax additionally to 15.07

\footnotetext{
${ }^{3}$ July 1, 2007, is first mentioned in a press release from the ministry of Finance in October 2006. This date was confirmed when the new policy was ratified in the parliament on 15 March 2007.
} 
Figure 1: The reductions in the payroll tax (a) and in the self-employment tax (b)

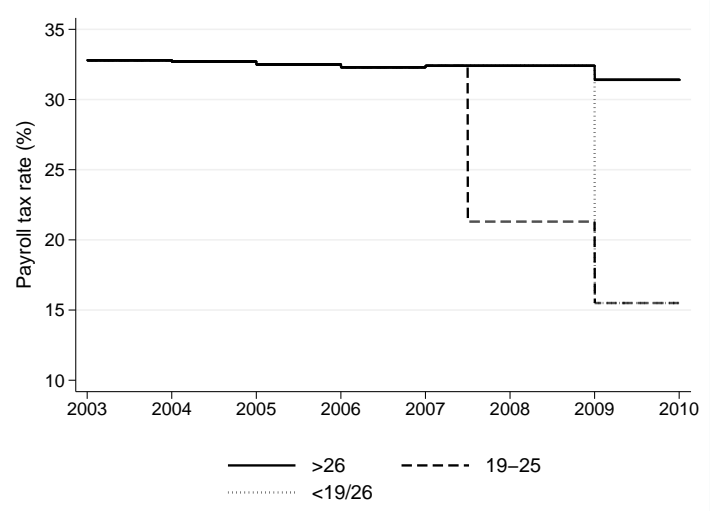

(a)

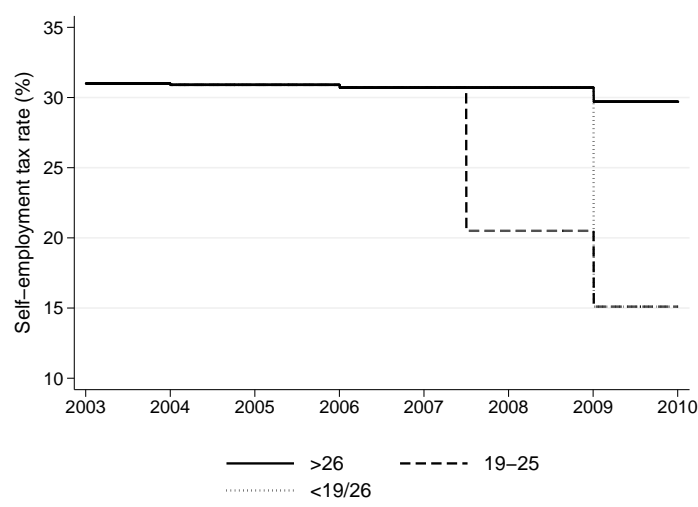

(b)

percent. Figure 2 illustrates how different cohorts are subjected to the payroll tax reductions (the reductions in the self-employment tax apply to the same cohorts). In 2007, the target group consists of individuals born 1982-88 whereas in 2008 it consists of those born 1983-89. For simplicity, hereafter an age group $a$ denotes all individuals who turn $a$ during the year. With this terminology, the target group of the 2007 reform is referred to as "individuals aged 19-25", and the target group of the 2009 reform as "individuals aged 26 or below". The group of 19-25 year-olds comprised around 10 percent of the labor force aged 15-64 in 2007, and so the number of individuals directly affected by the new regime was substantial. The tax reductions were automatically implemented via the tax system, meaning that neither employers nor the self-employed had to send in an application to benefit from the lower tax rates.

There are two types of businesses that you can run if you are self-employed in Sweden, an unincorporated or an incorporated firm. The absolute majority of young business owners run unincorporated firms. It is those who run unincorporated firms that pay the self-employment tax. Due to the reduced rate, a young person running an unincorporated firm pays a lower tax on her surplus, and hence has more money left at the end of the day (all else equal). She cannot use the surplus for dividends since there are no shareholders; what is left of the surplus after she has paid 
Figure 2: Evolution of treatment status across cohorts

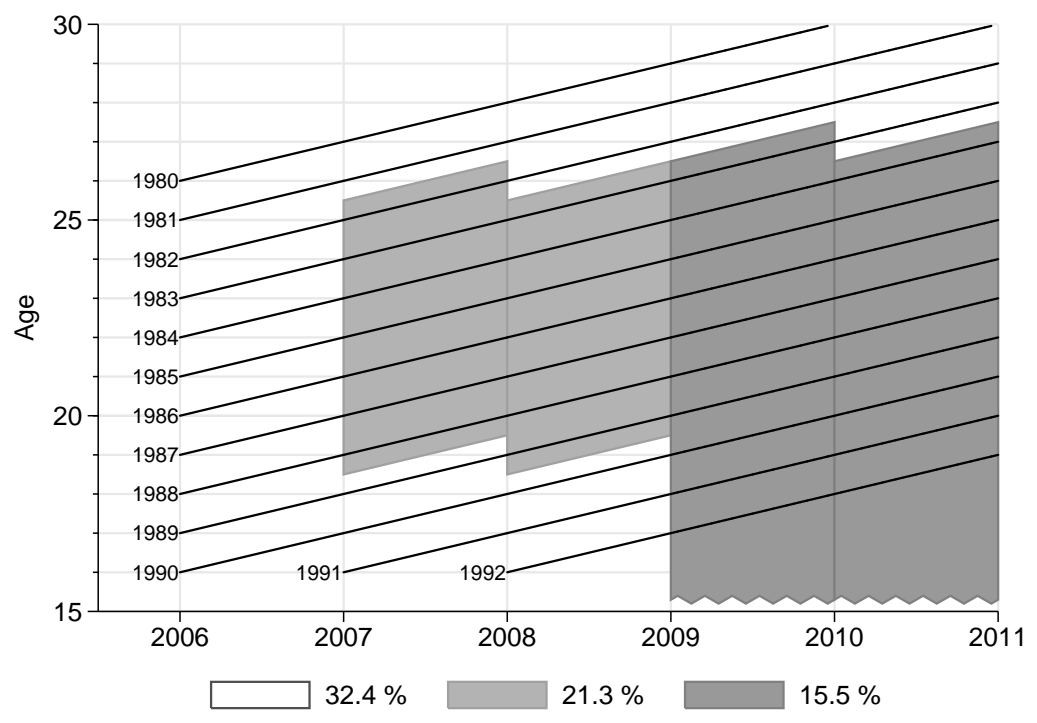

the self-employment tax is her (taxable) income that she reports to the tax authorities. Those who run incorporated firms pay payroll taxes, since they are seen as employees. (This organizational form has limited liability, but requires an initial capital investment of 50,000 SEK.) After the reform, a young person running an incorporated firm has a lower tax rate on his gross wage. Those who run incorporated firms can choose whether to use the surplus from the business as salary or to pay shareholders in the form of dividends. Dividends are taxed at the same rate $(30 \%)$, irrespective of age.

When analyzing the Swedish reform it is important to bear in mind that there is an asymmetry regarding tax incidence: whereas the payroll tax is levied upon employers, the self-employment tax falls directly on the person who is running the business. This means that the reform reduced one tax faced by employers, and one tax faced by the individual worker. ${ }^{4}$ The main purpose with these tax reductions was to decrease youth unemployment in general. Egebark and Kaunitz (2013) looks at how employers responded to the reduced payroll taxes. They find that the 2007 reduction led to a 2.5 percent employment increase, and that the estimated effect on wages was small, at around 1

\footnotetext{
${ }^{4}$ Of course, one could argue that the payroll tax ultimately falls on employees in the form of lower wages, at least in the long run.
} 
percent (resulting in a demand elasticity of -0.37). They also show that the extended payroll tax reduction, implemented in 2009, did not boost employment further. Skedinger (2014) evaluates the same payroll tax reductions, but focuses on the retail industry. His findings are in line with the results in Egebark and Kaunitz (2013).

\subsection{Other labor market reforms}

With the purpose of increasing employment, both in general and for specific groups, several labor market reforms were introduced in Sweden during 2007. First, temporary subsidies for firms that hire individuals who have been unemployed or have received sickness or disability benefits, New Start Jobs (NSJ), were introduced on January 1, 2007. In 2007-08, individuals aged 20-24 could apply for the subsidy after six months of non-employment, whereas those who had turned 25 could apply only after twelve months of non-employment; thus, in contrast to the payroll tax cut, it was the exact age that mattered. In 2009, this cutoff was modified so that those who at the start of the year have turned 20 but not 26 were eligible after six months. Consequently, in 2007-08 the target groups overlapped, and from 2009 onwards they completely coincide. In principle, this raises a concern that the estimates in this study will be contaminated. It turns out, however, that the number of applications for NSJ (available in the data) was comparatively low, at about 0.5 percent of the ages 20-26, and the difference in shares between 21-25 year-olds and 26-yearolds - the potential bias of the estimates - is around 0.1 percentage points. I thus conclude that this is not a source of concern.

Second, income tax deductions were introduced in Sweden on January 1, 2007, with the purpose of increasing labor supply in general. These deductions apply to all workers, regardless of age, but I cannot rule out that there is heterogeneity in labor supply effects with respect to age. If younger workers' labor supply responded differently, the estimates for the tax effect could potentially be biased. Edmark et al. (2012) show that it is difficult to evaluate this deduction scheme due to the lack of unaffected comparison groups; hence, we do not know exactly how different age groups responded. In this study I assume that the response was similar for individuals close in age.

Finally, a third reform concerns employment protection legislation. Loosening of regulation in 
2007 made it easier for employers to use fixed-term contracts. As temporary work is relatively more widespread among young workers, employment (and wages) may have been affected more for younger workers. However, Skedinger (2012) reports that only 1.4 percent of all temporary workers were employed with the new regulations in 2008. The reform, thus, had little impact in practice.

\section{Previous literature}

Previous research on the link between taxation and self-employment has primarily focused on the effect of income taxes. The effect of income taxes on the decision to become a business owner is theoretically ambiguous. On the one hand, high taxation may cause lower levels of self-employment since the expected return from running a risky business venture decreases. On the other hand, higher taxes make it more attractive to underreport taxable income. Hence, since underreporting is easier for the self-employed, there may be a positive effect. In addition, since most countries grant (various types of) loss offsetting, a higher tax may encourage risk taking due to the fact that the government's share of the loss increases with the tax rate (Domar and Musgrave, 1944). The theoretically ambiguous effect has lead researchers to turn to empirical evidence. So far, however, there is no consensus on the direction (and magnitude) of the effect (see Bruce, 2002, and Hansson, 2012, for brief summaries). This is true also for later work that uses individual level data instead of aggregated time-series. For example, Schuetze (2000) and Cullen and Gordon (2004) both find a positive correlation between income taxes and self-employment, whereas Gentry and Hubbard (2003) find no statistically significant correlation, and Gentry and Hubbard (2004) find a negative relationship. A final example is Hansson (2012), who uses Swedish data to show that income taxes are negatively correlated with the probability of becoming self-employed.

More recent work has focused less on the level of the income tax and more on the tax structure. Bruce $(2000,2002)$ analyzed how different taxation of income from employment and self-employment in the U.S. affects the choice to enter and exit self-employment. He found that larger individualspecific differences in marginal tax rates in the two sectors reduce self-employment entry rates: those with higher wage-and-salary minus self-employment differences (in expected marginal tax 
rates) are less likely to become self-employed. Bruce stresses the role of tax avoidance and evasion as one potential reason for this seemingly counterintuitive result. A contrasting example is Stabile (2004), who used different tax treatments in Canada to study occupational choice. He exploited the unexpected introduction of a payroll tax faced by employees, but from which self-employed were exempt, as a natural experiment. In particular, he compared the region of Ontario in Canada, where the new tax was introduced, to three other regions without the new tax. Contrary to the findings in Bruce's studies, Stabile showed that the payroll tax levied on employees had a positive effect on the probability of starting a business.

One drawback with many of the existing studies on the link between taxation and self-employment is that they do not use exogenous variation in taxes to estimate treatment effects, and so it can be questioned whether they estimate causal effects. (The most credible study in this respect is Stabile, 2004.) Instead, they rely heavily on creating synthetic tax rates, by using lags and leads, to control for the potential endogeneity that arises because an individual's decision to move into self-employment affects her income tax rate (i.e., in order to deal with simultaneity). Furthermore, these studies rely on econometric techniques such as, e.g., including inverse Mills ratios as controls to address the so-called initial conditions problem, which is essentially a bias due to omitted variables. I argue that this study offers a more credible identification strategy by making use of a Swedish reform that suddenly made taxes vary by age. Consequently, since I have well-defined treatment and control groups that can be followed over time in a Difference-in-Differences design, I should come closer to estimating the causal effect of taxes on the decision to become self-employed. ${ }^{5}$ Another advantage is that I use a tax change that is both immediate and substantial. Previous studies have mostly used fairly small variations in taxes seen over longer periods of time.

While this study ties in with the literature on taxes cited above, it also deals with a more specific question: how can employment opportunities for disadvantaged groups be improved? As pointed out by both the OECD and the European Commission, stimulating entrepreneurial activity could work as a way to lower unemployment for those who have a hard time finding a regular job, such as

\footnotetext{
${ }^{5}$ Since this study focuses on young individuals, one should bear in mind that the results may not generalize to the population in general. As pointed out by Bruce (2000), there are surprisingly few studies on youth self-employment. Important exceptions include Blanchflower and Meyer (1994) and Dunn and Holtz-Eakin (2000).
} 
youths and young adults (European Comission, 2013; OECD, 2013). ${ }^{6}$ So far there are few studies on how to increase self-employment among those with a weak attachment to the labor market, and so it is difficult for policymakers to know what approaches actually work (OECD, 2012, 2013). To the best of my knowledge there is no previous study on the effect of introducing tax reductions to support youth self-employment.

\section{Conceptual framework}

I study the effect on self-employment of a reform that simultaneously reduced the employer paid payroll tax and the tax paid by those who are self-employed. The purpose of the 2007-09 tax reforms was to reduce youth unemployment. The motivation for cutting the payroll-tax was to create an incentive for employers to hire young workers, by making the labor cost substantially lower (see, e.g., Gruber, 1997; Bennmarker et al., 2009; Huttunen et al., 2013). The reduced selfemployment tax, on the other hand, suddenly made it more attractive to be self-employed than to be unemployed, for those 19-25 years of age. (The prediction is that the net outflow from unemployment to self-employment increases.) This is the most obvious reason for why we would expect self-employment to increase for those in the target group, relative to older individuals. For a concrete example, compare a 25-year-old self-employed to a 26-year-old self-employed. As of July 1, 2007, the younger business owner has a competitive advantage due to the possibility to charge a lower price (all else equal). Or, she could keep prices unchanged and use the extra money for other purposes, such as investments, private consumption etc. In either case, the tax cut has made life easier for the younger self-employed. A reasonable prediction is, therefore, that individuals in the target group have a lower probability of transitioning from self-employment to unemployment (and, vice versa, a higher probability of transitioning from unemployment to self-employment).

It should also be useful to consider transitions between occupations in more detail (i.e., transitions from employment into self-employment and vice versa). Predictions about how transitions are affected are not as clear-cut. We might think that since the individual faces the self-employment

\footnotetext{
${ }^{6}$ There are many studies on whether or not stimulating self-employment is a good way of reducing unemployment. I will not review this literature here.
} 
tax himself, any change in this tax is more salient (Chetty et al., 2009). If the saliency of the tax is important, this may lead us to predict a reduced net outflow from self-employment to employment. On the other hand, if a large fraction of those that are self-employed are forced into this type of occupation, any change in the payroll tax that induces employers to start hiring may have the opposite effect on the net outflow (i.e., increased net outflow from self-employment). Since the direction of the effect appears to be ambiguous, this is in the end and empirical question. In the analysis below I therefore measure the effect on both the (overall) self-employment rate, and on occupational choice.

Income effects are, to some extent, more predictable. The reductions in the self-employment tax are implemented automatically through the tax system. Hence, all else equal, the size of the effect on income from self-employment is known. Any difference between this mechanical effect and the actual effect indicates the existence of behavioral adjustments.

\section{Data}

The data are collected by Statistics Sweden (SCB) and contain yearly information on employment status, income and demographical characteristics for all individuals living in Sweden who are at least 16 years of age, for the years 2002-09 (the Louise and RAMs data sets). The registers contain information on various types of income, including income from wage employment and from selfemployment. Even though I have information on individuals as young as 16 years of age, I will not consider the youngest individuals of the target group in the analysis. The reason for excluding 19-20 year-olds is that they turn out to be substantially different in terms of cyclicality, thus making comparisons over time difficult. I will thus focus on 21-25 year-olds in the following.

Table 1 presents 2006 summary statistics for individuals 21-27 years of age. The table shows that younger individuals (21-25 year-olds) have a lower probability of being employed, and of being self-employed. I use the definition of self-employment that is used by Statistics Sweden. First, an individual is defined as self-employed if the income she earns (in November) comes exclusively from the own firm. Second, if the individual has income both from an own firm and from employment, 
she is defined as self-employed if the income from the business multiplied by 1.6 is greater than the income from employment. ${ }^{7}$ (The definition of self-employment was slightly different before 2004.) Younger individuals further have lower incomes, both from employment and from self-employment. For both age groups, men are more likely to be self-employed; they also earn more than women, both as employed and as self-employed.

As is evident from table 1, it is only a small fraction of the young that run their own business. Table 2 follows three different groups of young individuals over time, and thus provides some understanding of who the young self-employed are. Columns 1-2 look at young employed, columns 3-4 at young self-employed, and columns 5-6 at somewhat older self-employed. Panel A considers unemployment risk. Compared to the young employed, the young self-employed have fewer days as registered unemployed, and a lower probability of being registered in the first place, both in 2006 and in 2008 (see columns 1-4). Looking at the two groups of self-employed (columns 3-6) we realize that there is basically no difference between them, neither in levels nor in trends. Since there are no changes across the two groups over time I conclude that the 2007 tax cut did not cause a compositional change in terms of unemployment risk. ${ }^{8}$

Panel B highlights some of the differences, and similarities, between the three groups in terms of industries. I have included the three industries where the employed mainly works, and the three industries where the self-employed mainly works. About 44 percent of the young employed works within the three industries listed first, i.e. within Health care, Manufacturing, or Retail. The corresponding figure for the young self-employed is instead 7-9 percent. For the next three industries it is more or less the opposite relationship that holds: 50 percent of the young selfemployed works within Construction, Hair/Body or Hotel/Restaurant, as compared to 21 percent for the young employed. The most striking difference is found for Hair/Body: roughly 15 percent of the self-employed are found in this industry, where less than one percent of the employed works.

I complement these numbers with figure 3 (a), which includes more industries and thus provides a more detailed comparison. One thing that is clear is that there are several industries where the

\footnotetext{
${ }^{7}$ The higher weight on income from the business is due to the fact that, for given levels of income, the number of hours spent working as self-employed is typically greater than the number of hours spent working as employed.

${ }^{8}$ Regression results confirm that there are no statistically significant compositional changes, for any of the characteristics presented in table 2 .
} 
Table 1: 2006 summary statistics by age group

\begin{tabular}{|c|c|c|c|}
\hline & \multicolumn{3}{|c|}{$21-25$ year-olds } \\
\hline & All & Men & Women \\
\hline Employed & $\begin{array}{c}65 \% \\
(\mathrm{~N}=536,859)\end{array}$ & $\begin{array}{c}65 \% \\
(\mathrm{~N}=274,716)\end{array}$ & $\begin{array}{c}65 \% \\
(\mathrm{~N}=262,143)\end{array}$ \\
\hline Self-employed & $\begin{array}{c}1.5 \% \\
(\mathrm{~N}=536,859)\end{array}$ & $\begin{array}{c}1.9 \% \\
(\mathrm{~N}=274,716)\end{array}$ & $\begin{array}{c}1.0 \% \\
(\mathrm{~N}=262,143)\end{array}$ \\
\hline Income from empl. ${ }^{a}$ & $\begin{array}{c}129,800 \\
(\mathrm{~N}=448,097)\end{array}$ & $\begin{array}{c}150,300 \\
(\mathrm{~N}=230,694)\end{array}$ & $\begin{array}{c}108,000 \\
(\mathrm{~N}=217,403)\end{array}$ \\
\hline \multirow[t]{3}{*}{ Income from self-empl. ${ }^{a}$} & $\begin{array}{c}66,740 \\
(\mathrm{~N}=7,912)\end{array}$ & $\begin{array}{c}69,200 \\
(\mathrm{~N}=5,318)\end{array}$ & $\begin{array}{c}61,600 \\
(\mathrm{~N}=2,594)\end{array}$ \\
\hline & \multicolumn{3}{|c|}{ 26-27 year-olds } \\
\hline & All & Men & Women \\
\hline Employed & $\begin{array}{c}69 \% \\
(\mathrm{~N}=221,914)\end{array}$ & $\begin{array}{c}70 \% \\
(\mathrm{~N}=113,233)\end{array}$ & $\begin{array}{c}67 \% \\
(\mathrm{~N}=108,681)\end{array}$ \\
\hline Self-employed & $\begin{array}{c}2.7 \% \\
(\mathrm{~N}=221,914)\end{array}$ & $\begin{array}{c}3.6 \% \\
(\mathrm{~N}=113,233)\end{array}$ & $\begin{array}{c}1.8 \% \\
(\mathrm{~N}=108,681)\end{array}$ \\
\hline Income from empl. ${ }^{a}$ & $\begin{array}{c}179,200 \\
(\mathrm{~N}=185,715)\end{array}$ & $\begin{array}{c}203,700 \\
(\mathrm{~N}=95,892)\end{array}$ & $\begin{array}{c}153,100 \\
(\mathrm{~N}=89,823)\end{array}$ \\
\hline Income from self-empl. ${ }^{a}$ & $\begin{array}{c}80,400 \\
(\mathrm{~N}=6,044)\end{array}$ & $\begin{array}{c}85,600 \\
(\mathrm{~N}=4,131)\end{array}$ & $\begin{array}{c}69,200 \\
(\mathrm{~N}=1,913)\end{array}$ \\
\hline
\end{tabular}

${ }^{a}$ Yearly income in SEK. 
Table 2: Comparing levels and trends across three subgroups

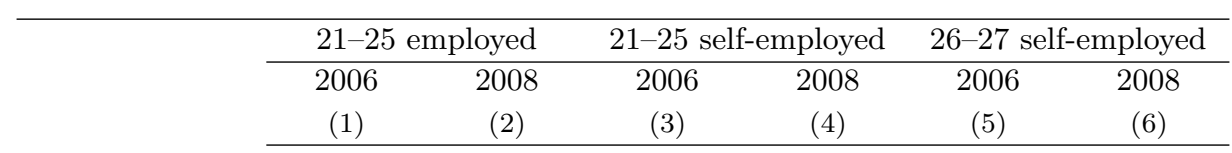

Panel A: Unemployment risk, previous year

$\begin{array}{ccccccc}\text { Days unempl. } & 23.4 & 14.5 & 15.3 & 8.5 & 15.6 & 8.2 \\ & (52.1) & (42.2) & (45.0) & (33.9) & (51.7) & (38.0) \\ \text { Prob. unempl. } & 0.28 & 0.17 & 0.17 & 0.10 & 0.14 & 0.08 \\ & (0.45) & (0.37) & (0.38) & (0.30) & (0.35) & (0.27)\end{array}$

Panel B: Industries

$\begin{array}{lcccccc}\text { Health care } & 19 \% & 18 \% & 0.5 \% & 0.6 \% & 0.9 \% & 0.8 \% \\ \text { Manufacturing } & 13 \% & 13 \% & 2.3 \% & 2.1 \% & 2.7 \% & 2.6 \% \\ \text { Retail } & 12 \% & 12 \% & 6.6 \% & 4.6 \% & 5.2 \% & 4.1 \% \\ & & & & & & \\ \text { Construction } & 12 \% & 13 \% & 26 \% & 26 \% & 31 \% & 32 \% \\ \text { Hair/Body } & 0.6 \% & 0.6 \% & 13 \% & 15 \% & 11 \% & 11 \% \\ \text { Hotel/Rest } & 7.1 \% & 7.2 \% & 10 \% & 7.5 \% & 7.2 \% & 7.2 \%\end{array}$

Panel C: Parent characteristics

\begin{tabular}{lllllll} 
Father's inc. $^{a}$ & 277,000 & 296,000 & 251,000 & 262,000 & 234,00 & 240,000 \\
Mother's inc. $^{a}$ & 204,000 & 225,000 & 186,000 & 202,000 & 183,00 & 199,000 \\
& & & & & & \\
\hline
\end{tabular}

Notes: Unemployment risk refers to the previous year. ${ }^{a}$ Yearly income in SEK. 
Figure 3: Industry comparisons

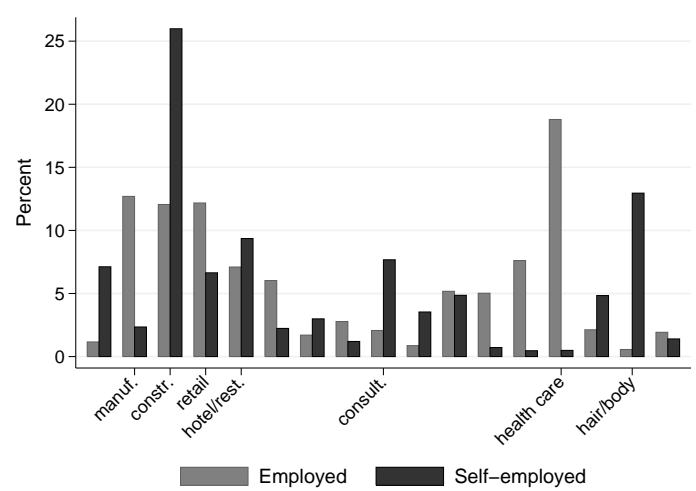

(a) $21-25$ year-olds in 2006

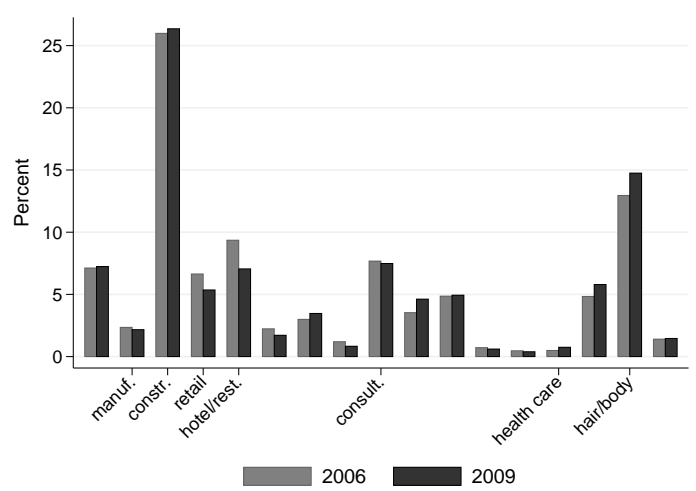

(b) Self-employed 21-25 year-olds

difference between the two groups is substantial. Columns 3-6 of panel B show that the two groups of self-employed are very similar also in terms of the industries where they are active. As before, since there are no changes across the groups over time, there is no compositional effect in this dimension either. Figure 3 (b) provides an illustration of how stable industry composition is over time.

Finally, panel C shows some slight differences with respect to parents' income. We notice that parents' income is higher for the employed, and that the parents of the young self-employed earn more than the parents of the older self-employed. 


\section{Identification}

I use the Difference-in-Differences (DiD) estimator to capture the effect of the tax cuts on selfemployment and income. I estimate the following model:

$$
y_{i, t}=\delta_{t} \cdot D(i, t)+\mathbf{x}_{i, t}^{\prime} \boldsymbol{\beta}+\varepsilon_{i, t}
$$

where $y_{i, t}$ indicates whether individual $i$ is self-employed in year $t, D(i, t)$ is a treatment indicator for individual $i$ in year $t, \delta_{t}$ is the DiD estimate for year $t$, and $x_{i, t}$ is a vector of control variables. This vector includes dummy variables for year, age, gender and whether being foreign-born, and indicators for local labor market. When studying income, the only thing that changes is the outcome variable, $y_{i, t}$.

DiD uses the evolution of the control group over time as a measure of how the treatment group would have evolved, had the intervention not taken place. The key assumption is, hence, that the two groups would have moved in parallel in absence of treatment. This parallel trends assumption is, by definition, not testable since it concerns counterfactual outcomes. However, to get an indication of whether it is likely to hold it is important to confirm that the evolution of the treatment and control groups are similar before the intervention took place. In the analysis below I therefore estimate treatment effects also for the years before the tax reductions was in place.

An implication of the DiD identifying assumption is that the control group must not be affected by the intervention under study. If such treatment spillovers exist, DiD will not measure the difference between the reform outcome and the counterfactual outcome, but the difference to the control group deviation from its counterfactual outcome. Consequently, we obtain a measure of the relative rather than the absolute effect of the reform. In the present case I cannot rule out that age groups just above the treatment-defining cutoff are unaffected. For example, the tax cut gives 25-year-olds the opportunity to compete with 26-year-olds by reducing prices; this would certainly affect 26-year-olds ability to continue running their businesses. Hence, using 26-year-olds as the control group in the above DiD-model may overestimate the absolute effect. With this in mind I estimate the (relative) effect using both the 25-26 and the 21-27 age-intervals. (Using a larger 
bandwidth should also, at least to some extent, handle different types of cohort heterogeneity.)

A second issue with using $\mathrm{DiD}$ in this case is that it gets increasingly difficult to find a control group that has not been subjected to the tax reduction in the past. For example, comparing 25year-olds to 26-year-olds implies that the control group in 2008 (those born 1982) was in the target group the year before (see figure 2 in section 2.2). Ultimately, this means that it is hard to identify the reform effect for the later years in the sample. One way to handle this issue would be to use 27-year-olds instead of 26-year-olds as the control group. In the analysis below I experiment with altering the control group in this way.

As described in section 2.2 above, the 2007 tax cuts were extended in 2009. If the initial reduction had an impact, it is, due to the problems described above, difficult to evaluate the 2009 reduction. However, in absence of any earlier impact, the parallel trends assumption is more likely to hold. The most straightforward way would then be to compare $25-26$ year-olds to $27-28$ year-olds in 2009: 26-year-olds transition from no treatment straight to 2009 treatment while 25-year-olds transition from 2007 treatment to 2009 treatment. ${ }^{9}$ By considering the later years in the sample I will be able to uncover whether the effect differs as the economy is hit by the financial crisis. This is important since it helps shed light on whether financially stimulating self-employment, in the form of tax reductions, works better in times of economic slowdowns.

\section{$7 \quad$ Results}

\subsection{Main findings}

A first look at the data clearly indicates that youth self-employment was unaffected by the 2007 tax changes. Figure 4 (a) shows how the self-employment rate-here defined as the fraction of self-employed in the population as a whole - depends on age, before and after the 2007 reform. As is seen, the distribution looks very similar between 2006 and 2008, especially if we focus on ages 24-26. The fact that nothing seems to happen around the cut-off (indicated by the vertical line)

\footnotetext{
${ }^{9}$ This comparison hinges on the assumption that there are no effects of the initial 2007 reductions. Below I discuss whether this assumption appears to be valid empirically.
} 
Figure 4: Self-employment rates before and after the 2007 tax cut

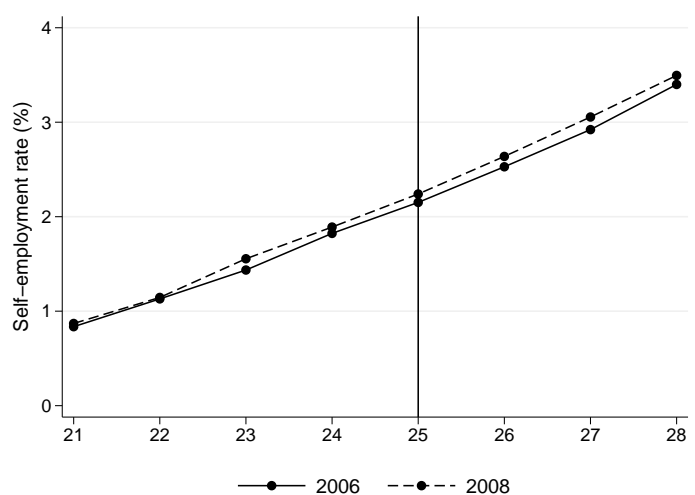

(a) Full sample

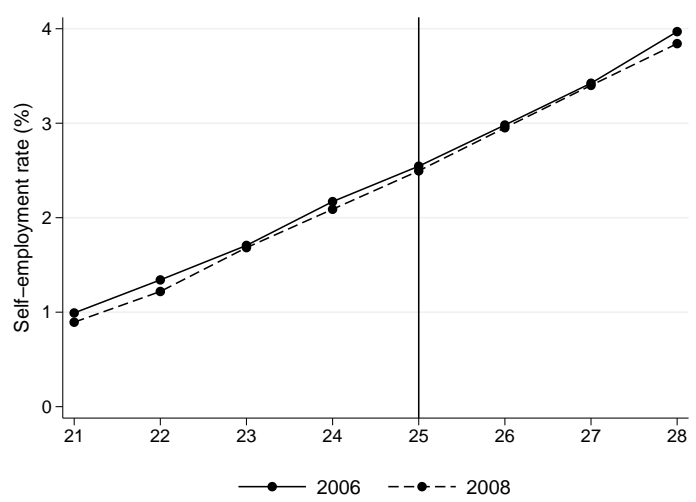

(b) Conditional on working in 2006

suggests that the propensity to be self-employed did not increase for the younger individuals. As described in section 4 , it is also useful to consider transitions between occupations in more detail (i.e., transitions from employment into self-employment and vice versa). ${ }^{10}$ A simple way to test whether the choice of occupation was affected is to narrow the sample to individuals that were either employed or self-employed in 2006, i.e., the year before the tax cut was implemented. Figure 4 (b) gives the age distributions before and after the reform, for the smaller sample. (Excluding those not employed or self-employed in 2006 increases the self-employment rate slightly.) Neither for this sample there are any visible changes around the cutoff. (If anything, the propensity to be self-employed seems to decrease for younger individuals relative to older ones.)

The main message from the graphical evidence is that youth self-employment was unaffected by the tax reductions up until 2008. This conclusion is supported by DiD-estimates in tables 3 and 4 . Both tables report treatment effects for different age groups, using 26-27 year-olds as the control group. When I study self-employment in the following I chose to exclude years 2002-03. The reason for this is twofold. First, precision is higher when using the shorter time period, making it easier to

\footnotetext{
${ }^{10}$ For the self-employment rate in figure 4 (a) to be constant, any increase (decrease) in the net inflow from employment to self-employment has to be compensated (exactly) by increased (decreased) net outflow from selfemployment to non-employment. Hence, already the result that the self-employment rate in figure 4 (a) is unaffected could be taken as an indication that there is no effect on transitions.
} 
draw strong conclusions. In particular, focusing on a small time window around the time of the tax reform makes it easier to detect even small changes in the outcome; as will be clear, I do not find any significant effects even with the narrow window, and these null results are precisely estimated. A second argument for not using 2002-03 is that the definition of self-employment changes in 2004 (see section 5). Importantly, using the longer time period does not produce any substantially different results. To facilitate readability I have multiplied all the coefficients in the tables by 100 , and so the point estimates represent percentage points.

Table 3 shows pooled treatment effects, for each of the two samples used in figures 4 (a) and 4 (b). (This is the simplest possible model in the sense that it groups years 2004-06 and 2007-08, respectively.) Evidently, the reductions had no effect on youth self-employment. First, there are no statistically significant effects for any of the samples, irrespective of what age-interval is used. Second, consider for example the full sample: we can be $95 \%$ confident that any (positive) effect for 21-25 year-olds is no greater than 0.06 percentage points (i.e., the upper bound for a $95 \%$-confidence interval is 0.058 percentage points).

Table 4 gives a more detailed picture by reporting DiD-estimates (in percentage points) for each year 2006-08. The reason for including the treatment effect for 2006 is to examine whether the trends prior to the policy intervention are the same in treatment and control groups. The fact that the pre-treatment effects are statistically insignificant, and precisely estimated, lends credibility to the identifying assumption of parallel trends. In general, the results in table 4 support the findings from above.

Since there is no treatment effect for 25 -year-olds in 2007 , the issue of a lagged treatment effect for the control group in 2008 is less of a problem. Nevertheless, to address the bias discussed in section 6, I have also tried using only 27-year-olds as the control group in all of the above specifications (thus excluding 26-year-olds). As is seen in tables A.1 and A.2 in the appendix, all of the above results are robust to this change. As a second sensitivity test, I have tried changing the definition of self-employment in table A.3 in the appendix. Instead of using the dummy variable described in section 5 as outcome, I use a dummy variable that equals one if an individual has non-zero income from self-employment (and zero if income from self-employment is zero). I thus disregard the fact 
Table 3: Pooled effects (in percentage points) by sample and age group

\begin{tabular}{|c|c|c|c|c|}
\hline & \multicolumn{2}{|c|}{ FULL SAMPLE } & \multicolumn{2}{|c|}{ CONDITIONAL } \\
\hline & TG: 25 & TG: $21-25$ & TG: 25 & TG: $21-25$ \\
\hline DD $07-08$ & $\begin{array}{c}-0.002 \\
(0.060)\end{array}$ & $\begin{array}{l}-0.011 \\
(0.035)\end{array}$ & $\begin{array}{l}-0.003 \\
(0.069)\end{array}$ & $\begin{array}{l}-0.037 \\
(0.041)\end{array}$ \\
\hline $\bar{y}_{\mathrm{TG}}$ & 2.2 & 1.5 & 2.5 & 1.7 \\
\hline$N$ & $1,091,071$ & $3,804,593$ & 909,945 & $3,170,954$ \\
\hline$R^{2}$ & 0.003 & 0.005 & 0.004 & 0.006 \\
\hline \multicolumn{5}{|c|}{$\begin{array}{l}\text { Notes: }{ }^{* * *} p<1 \%, * * p<5 \%,{ }^{*} p<10 \% \text {. The outcome is a dummy variable } \\
\text { for being self-employed in a given year. Point estimates represent percentage } \\
\text { points. } \bar{y}_{\mathrm{TG}} \text { gives the treatment group average (in percent) in the treatment } \\
\text { period. Years } 2004-06 \text { constitute the reference period. While the definition of } \\
\text { the treatment group (TG) varies, the control group consists of } 26-27 \text { year-olds. } \\
\text { The conditional sample uses those who work in } 2006 \text {. Fixed effects included } \\
\text { for year, age and demographic characteristics (see section } 6 \text { ). Robust standard } \\
\text { errors in parenthesis. }\end{array}$} \\
\hline
\end{tabular}

that an individual might have income from wage employment. With this alternative definition, I can examine whether the lower self-employment tax caused a young person to at least try to start a business (since filing a positive or negative income amount indicates that the individual has a business of some kind). Strikingly, even for this (very liberal) definition of self-employment, the lack of treatment effects is precisely estimated.

Finally, I have experimented with smaller sub-samples to find out if there exist any heterogeneous treatment effects (see table A.4 in the appendix). First, I have run separate regressions for men, women, natives, foreign-born, and those with vocational training. For vocational training I have considered both a broad group and a smaller, more homogenous, group. ${ }^{11}$ None of these six groups display any significant effects. (For foreign-born and the vocationally trained, where samples sizes are smaller, the null results are less precise.) Second, previous research suggests that the response to tax changes depends, to a large degree, on how aware people are of new tax rules.

\footnotetext{
${ }^{11}$ I restrict the sample to individuals who, at age 22 at the latest, have finished three years of vocational training. Vocational training in Sweden is relatively broad; it includes for example musical and art training. The more homogenous group consists of, e.g., carpenters, painters, plumbers and electricians.
} 
Chetty et al. (2013), for example, show that labor supply effects of the Earned Income Tax Credit vary substantially across neighborhoods: individuals in high-knowledge areas change wage earnings sharply to obtain larger EITC refunds relative to those in low-knowledge areas. This finding suggests that individuals with better knowledge about the 2007 tax reform could have responded differently. It seems reasonable to expect that individuals whose parents are self-employed are more aware of the tax change, and, to some extent, we may also expect those with high income parents to have better knowledge. Hence, I run separate regressions for those that have either a mother or a father who is self-employed, and for those with high income parents. As is seen in the bottom panel of table A.4, there are no significant effects for any of these subsamples either. While this could indicate that knowledge was less important in the present case, we should also note that for those with self-employed parents the estimates are less precise. In other words it is difficult to draw strong conclusions.

Table 5 studies the extended tax reductions that were implemented in 2009. As discussed in section 6, I use 25-26 year-olds as the treatment group, and 27-28 year-olds as the control group. The easiest way to examine whether the 2009 additional reductions had an impact is to contrast 2009 to 2004-08. This is done for each of the respective samples in columns 1 and 3 . The fact that the 2009 estimate is statistically insignificant and precisely estimated clearly speaks against any impact. Since the comparison is based on the assumption that there are no effects of the 2007 initial tax reductions, I have also allowed for treatment effects for each year 2007-09 in columns 2 and 4. The estimates for the pre-treatment years are insignificant, but somewhat large (in absolute terms). ${ }^{12}$ Even though the common trends assumption is somewhat less credible in table 5 , it seems reasonable to conclude that there was no effect of the 2009 reduction. This result is important since it indicates that youth self-employment is insensitive to tax reductions also in times of economic slowdowns.

\footnotetext{
${ }^{12}$ The fact that the estimates appear to jump above and below zero depending on year could indicate that it is just random shocks.
} 
Table 4: Yearly effects (in percentage points) by sample and age group

\begin{tabular}{|c|c|c|c|c|}
\hline & \multicolumn{2}{|c|}{ FULL SAMPLE } & \multicolumn{2}{|c|}{ CONDITIONAL } \\
\hline & TG: 25 & TG: $21-25$ & TG: 25 & TG: $21-25$ \\
\hline \multirow[t]{2}{*}{ DD 2006} & 0.016 & 0.023 & -0.004 & -0.060 \\
\hline & $(0.079)$ & $(0.047)$ & $(0.092)$ & $(0.055)$ \\
\hline \multirow[t]{2}{*}{ DD 2007} & 0.014 & 0.026 & 0.027 & -0.019 \\
\hline & $(0.080)$ & $(0.047)$ & $(0.092)$ & $(0.054)$ \\
\hline \multirow[t]{2}{*}{ DD 2008} & -0.007 & -0.031 & -0.025 & -0.095 \\
\hline & $(0.080)$ & $(0.047)$ & $(0.093)$ & $(0.055)$ \\
\hline $\bar{y}_{\mathrm{TG}}$ & 2.4 & 1.5 & 2.5 & 1.7 \\
\hline$N$ & 1091071 & 3804593 & 909945 & 3170954 \\
\hline$R^{2}$ & 0.003 & 0.005 & 0.004 & 0.006 \\
\hline
\end{tabular}

Notes: ${ }^{* * *} p<1 \%,{ }^{* *} p<5 \%,{ }^{*} p<10 \%$. The outcome is a dummy variable for being self-employed in a given year. Point estimates represent percentage points. $\bar{y}_{\text {TG }}$ gives the treatment group average (in percent) in the treatment period. Years 2004-05 constitute the reference period. While the definition of the treatment group (TG) varies, the control group consists of $26-27$ year-olds. The conditional sample uses those who work in 2006. Fixed effects included for year, age and demographic characteristics (see section 6). Robust standard errors in parenthesis. 
Table 5: Effects of 2009 extension (percentage points)

\begin{tabular}{|c|c|c|c|c|}
\hline & FULL & AMPLE & COND & IONAL \\
\hline & $25-26$ & . $27-28$ & $25-26$ & . $27-28$ \\
\hline DD 2007 & & 0.053 & & 0.082 \\
\hline & & $(0.057)$ & & $(0.066)$ \\
\hline DD 2008 & & -0.049 & & -0.029 \\
\hline & & $(0.057)$ & & $(0.067)$ \\
\hline DD 2009 & -0.005 & -0.005 & -0.006 & 0.004 \\
\hline & $(0.055)$ & $(0.058)$ & $(0.065)$ & $(0.068)$ \\
\hline $\bar{y}_{\mathrm{TG}}$ & 2.6 & 2.6 & 2.8 & 2.8 \\
\hline$N$ & $2,647,469$ & $2,647,469$ & $2,647,469$ & $2,647,469$ \\
\hline$R^{2}$ & 0.004 & 0.004 & 0.005 & 0.005 \\
\hline $\begin{array}{l}\text { Notes: } * * * \\
\text { for being se } \\
\text { points. } \bar{y}_{\mathrm{T}} \\
\text { period. Ye } \\
\text { and } 3 \text { ( } 2 \text { an } \\
\text { effects inclu } \\
\text { Robust star }\end{array}$ & $\begin{array}{l},{ }^{* *} p<5 \% \\
\text { oyed in a } \mathrm{g} \\
\text { the treatm } \\
4-08 \text { (2004- } \\
\text { The conditio } \\
\text { year, age } \\
\text { rors in pare }\end{array}$ & $\begin{array}{l}0<10 \% \text {. } \\
\text { year. Po } \\
\text { group aver } \\
\text { constitute } \\
\text { sample us } \\
\text { demograp } \\
\text { esis. }\end{array}$ & $\begin{array}{l}\text { tcome is a d } \\
\text { mates repres } \\
\text { percent) in } \\
\text { rence perio } \\
\text { e who work } \\
\text { racteristics }\end{array}$ & $\begin{array}{l}\text { nmy variable } \\
\text { th percentage } \\
\text { he treatment } \\
\text { in columns } 1 \\
\text { 2006. Fixed } \\
\text { e section } 6 \text { ). }\end{array}$ \\
\hline
\end{tabular}




\subsection{Income}

The previous section provides convincing evidence against any effects on the extensive margin. This section uncovers adjustments along the intensive margin, by studying the effect on income. I examine both whether the lower taxes caused self-employed individuals to allocate more time to selfemployment, and whether they reallocated time between wage employment and self-employment. I do this by simply comparing the estimated effect on income from self-employment to the predicted mechanical effect (i.e., the effect that exists irrespectively of behavior adjustments). While intensive margin responses to tax changes have proven difficult to detect in the past, recent work shows that such adjustments can be substantial (Chetty et al., 2013).

Figure 5 shows income from self-employment by age, for years 2006 and 2008, respectively. In 2006, just before the tax reform was implemented, income grows continuously with age (grey bars). In contrast, the 2008 distribution shows a sharp increase for those below the treatment defining age cutoff (black bars). While income is lower in 2008 than in 2006 for those above 25 years of age, this is clearly not the case for those below the cutoff. The income effect is substantial: close to the cutoff it pushes young individuals' earnings well above the level of older age groups.

Another striking result is given in figure 6, where I contrast 26-year-olds to 28-29 year-olds. (The reason for using 28-29 year-olds as control is that they are unaffected the whole period.) For 26-year-olds we do not expect any effect until 2009 when the target group was extended. In addition, we should expect a rather sharp increase this year, since for this age group the tax was cut by 15 percentage points at once. Figure 6 shows that, while relative income is (more or less) constant up until 2008, there is a sharp increase for 26-year-olds in 2009. Strikingly, the tax cut shoots income for the younger individuals above the level of the older ones.

The conclusions from the figures are strengthened by DiD estimations in tables 6 and 7 . Table 6 gives pooled 2007-09 treatment effects for different age groups, using 28-29 year-olds as the control group. The pooled effects are highly significant and large in magnitude, irrespectively of whether I use small or large bandwidths. For 21-25 year-olds income has increased by as much as 20 percent. ${ }^{13}$

Pooling the income effect is useful for demonstrating the presence of a general treatment effect

\footnotetext{
${ }^{13}$ The estimated percentage increase is relative to the counterfactual outcome. It is, thus, obtained as $\beta /\left(\bar{y}_{\mathrm{TG}}-\beta\right)$.
} 
Figure 5: Income distributions before and after the 2007 tax cut

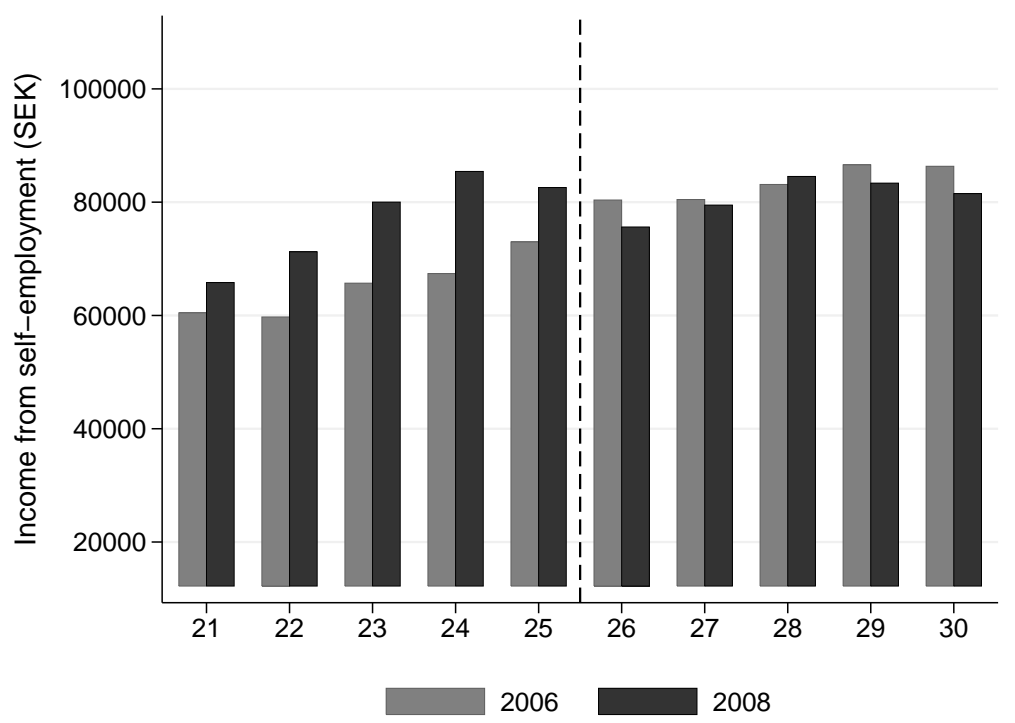

Figure 6: Income effect for 26-year-olds

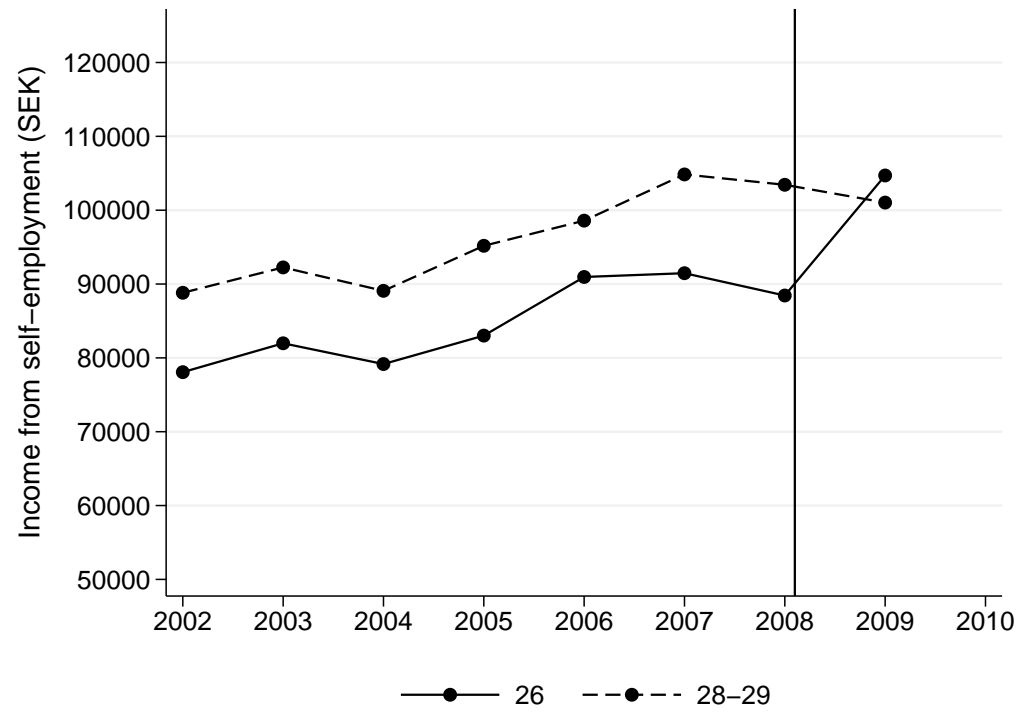


Table 6: Pooled income effects, by age group

\begin{tabular}{|c|c|c|c|}
\hline & \multicolumn{3}{|c|}{ Income from self-employment (SEK) } \\
\hline & TG: 25 & TG: $23-25$ & TG: $21-25$ \\
\hline DD 07-09 & $\begin{array}{c}9,790^{* * *} \\
(1,800)\end{array}$ & $\begin{array}{c}12,150^{* * *} \\
(1,350)\end{array}$ & $\begin{array}{c}12,870 * * * \\
(1,230)\end{array}$ \\
\hline $\bar{y}_{\mathrm{TG}}$ & 81,350 & 79,730 & 76,990 \\
\hline$N$ & 103,522 & 140,350 & 162,721 \\
\hline$R^{2}$ & 0.02 & 0.02 & 0.02 \\
\hline Effect size: & $14 \%$ & $18 \%$ & $20 \%$ \\
\hline \multicolumn{4}{|c|}{$\begin{array}{l}\text { Notes: }{ }^{* * *} p<1 \%,{ }^{*} p<5 \%,{ }^{*} p<10 \% \text {. The outcome is yearly } \\
\text { income from self-employment in SEK. }{ }_{\text {TG }} \text { gives the treatment group } \\
\text { average (in SEK) in the treatment period. Years } 2002-06 \text { constitute } \\
\text { the reference period. While the definition of the treatment group } \\
\text { (TG) varies, the control group consists of } 28-29 \text { year-olds. Fixed } \\
\text { effects included for year, age and demographic characteristics (see } \\
\text { section } 6 \text { ). Robust standard errors in parenthesis. }\end{array}$} \\
\hline
\end{tabular}

in the after period. However, yearly effects are hidden, and so we may miss out on interesting patterns in the data. Figure 1 (b) above shows that the first tax cut only applied to the second half of 2007 whereas in 2008 it applied to the whole year. In addition, there was an extended reduction in 2009 (from 20.45 to 15.07 percent). This means that we expect the income effect to increase in 2008 and in 2009, relative to 2007. Table 7, which gives yearly treatment effects, proves that the effect is in fact growing over time. In absolute terms, the 2009 effect is more than twice as large as the 2007 effect (as shown by columns 1-3). The positive effects on income is unlikely to be driven by age specific cyclicality, since they appear both when the economy was expanding in 2007-08, and when the economy was contracting dramatically in 2009. Column 4 of table 7 confirms what we saw in figure 6: 26-year-olds show a sharp increase in 2009, but not before. The last column is included as a simple placebo test; it shows that 27-year-olds, as we should expect, are unaffected during the whole period.

All of the pre-treatment point estimates in table 7 are insignificant and close to zero. This 
Table 7: Yearly income effects, 2005-09, by age group

\begin{tabular}{|c|c|c|c|c|c|}
\hline & \multicolumn{5}{|c|}{ Income from self-employment (SEK) } \\
\hline & $\begin{array}{c}\text { TG: } 25 \\
\text { (1) }\end{array}$ & $\begin{array}{c}\text { TG: } 23-25 \\
(2)\end{array}$ & $\begin{array}{c}\text { TG: } 21-25 \\
(3)\end{array}$ & $\begin{array}{c}\text { TG: } 26 \\
\text { (4) }\end{array}$ & $\begin{array}{c}\text { TG: } 27 \\
(5)\end{array}$ \\
\hline DD 2005 & $\begin{array}{l}1,720 \\
(2,500)\end{array}$ & $\begin{array}{c}290 \\
(1,850)\end{array}$ & $\begin{array}{c}890 \\
(1,700)\end{array}$ & $\begin{array}{c}-1,740 \\
(2,320)\end{array}$ & $\begin{array}{c}-130 \\
(2,490)\end{array}$ \\
\hline DD 2006 & $\begin{array}{c}-370 \\
(2,480)\end{array}$ & $\begin{array}{c}63 \\
(1,890)\end{array}$ & $\begin{array}{c}910 \\
(1,760)\end{array}$ & $\begin{array}{c}760 \\
(2,460)\end{array}$ & $\begin{array}{c}-3,100 \\
(2,440)\end{array}$ \\
\hline DD 2007 & $\begin{array}{c}3,065 \\
(2,800)\end{array}$ & $\begin{array}{c}5,390 * * \\
(2,120)\end{array}$ & $\begin{array}{c}8,130^{* * * *} \\
(1,930)\end{array}$ & $\begin{array}{c}-1,095 \\
(2,670)\end{array}$ & $\begin{array}{c}-1,490 \\
(2,740)\end{array}$ \\
\hline DD 2008 & $\begin{array}{c}9,730^{* * *} \\
(3,000)\end{array}$ & $\begin{array}{c}13,150^{* * *} \\
(2,250)\end{array}$ & $\begin{array}{c}13,060^{* * *} \\
(2,000)\end{array}$ & $\begin{array}{l}1,840 \\
(2,850)\end{array}$ & $\begin{array}{l}1,130 \\
(2,850)\end{array}$ \\
\hline DD 2009 & $\begin{array}{c}16,600^{* * *} \\
(2,900)\end{array}$ & $\begin{array}{c}17,240^{* * *} \\
(2,180)\end{array}$ & $\begin{array}{c}17,930 * * * \\
(1,990)\end{array}$ & $\begin{array}{c}13,300^{* * *} \\
(2,970)\end{array}$ & $\begin{array}{c}3,830 \\
(2,640)\end{array}$ \\
\hline $\bar{y}_{\mathrm{TG}}$ & 81,350 & 79,730 & 76,990 & 85,120 & 81,350 \\
\hline$N$ & 103,522 & 140,350 & 162,721 & 107,802 & 103,522 \\
\hline$R^{2}$ & 0.018 & 0.017 & 0.018 & 0.018 & 0.018 \\
\hline
\end{tabular}

suggests that the parallel trends assumption holds, and so it is likely that the estimated income increases have a causal interpretation. However, the standard errors reported in the tables do not handle serial correlation in the error term (i.e., they are not clustered at any level). We may therefore worry that the significant income effects are the result of downward biased standard errors. Table A.5 in the appendix repeats the exercise of table 7, but with standard errors that are robust to two different types of clustering. Evidently, clustering does not change any of the conclusions. The reason that I prefer to use the robust standard errors in table 7 is that they are larger than any of the cluster robust errors (Angrist and Pischke, 2009).

So far we have seen that the 2007-09 tax reductions caused income from self-employment to grow substantially. What is important to understand at this stage is whether the estimated income effect 
exceeds the mechanical effect. The 2007 payroll tax reduction lowered the tax rate from 30.71 to 20.45 percent whereas the 2009 reduction lowered the rate down to 15.07 percent. All else equal, we thus expect income to increase by 7.4 percent in 2007, 14.8 percent in 2008, and by 22.6 percent in 2009 , relative to the period before the changes. ${ }^{14}$ Figure 7 shows the predicted percentage increases (grey bars) as well as the estimated percentage effects for 21-25 year-olds (black bars). Evidently, the estimated effect exceeds the mechanical effect each year 2007-09. This is important since it could indicate a labor supply adjustment along the intensive margin: the age groups that suddenly faced the lower tax may have increased the number of hours spent in self-employment - either by reducing leisure or time in wage employment. (I will come back to alternative explanations for the pattern in figure 7 later in this section.) It is easy to quantify the behavioral change. We note that the average yearly difference between the mechanical and the estimated effect, for 21-25 year-olds in 2007-09, is roughly SEK 3,250. ${ }^{15}$ Furthermore, since the market wage for a typical 21-25 year-old worker is around SEK 100-125 per hour, the estimated adjustment corresponds to 26-32 hours per year. (The increase in working hours could be even bigger since the self-employed most likely earn less than the market wage.)

An interesting question from a policy perspective is how lasting the income effect is. We know that some cohorts, essentially because of luck, were allowed a lower tax rate for a limited period of time. The cohort that was born in 1982, for example, faced the lower tax rate for one year, in 2007. Does this mean that their income in 2008 - when they are 26 and no longer eligible - increased as well? Figure 8 shows that this is not the case: the 1982 cohort experiences an income shock in 2007, but the effect disappears already the following year. In other words, the days with substantially higher income appears to have been temporary. This, in turn, means that any potential increase in working hours was short lived, i.e., there was no spillover effect to consecutive years when the tax rate went back to normal levels. In a broader perspective, this suggests that temporary tax cuts (even though they are substantial) will have no lasting effects on intensive margin labor supply.

\footnotetext{
${ }^{14}$ The 2007 effect is calculated assuming that income is evenly distributed across the first and the last six months of the year.

${ }^{15}$ In absence of a treatment effect, average income from self-employment for 21-25 year-olds in 2007-09 is SEK $76,990-12,870=$ SEK 64,120 (see column 3 of table 6 ). The average yearly mechanical effect is 15 percent in 200709, which corresponds to SEK 9,618 (15 percent of SEK 64,120). Finally, the amount by which the estimated effect exceeds the mechanical effect is SEK $12,870-9,618=$ SEK 3,252 .
} 
Figure 7: Differences between mechanical and estimated effects

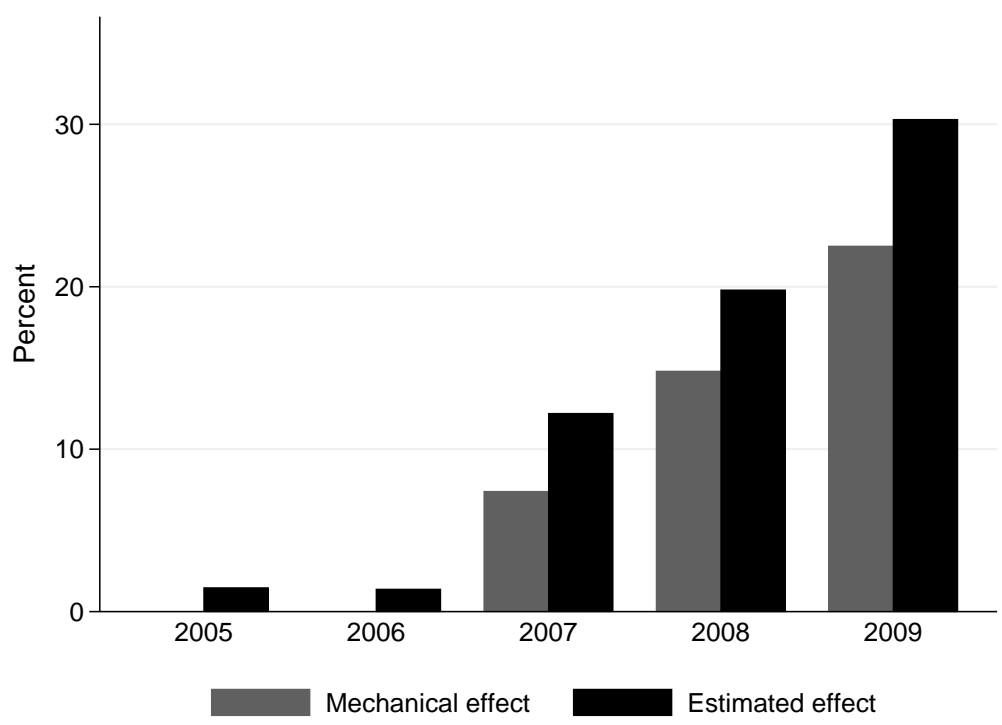

Figure 8: Persistence of 2007 effect

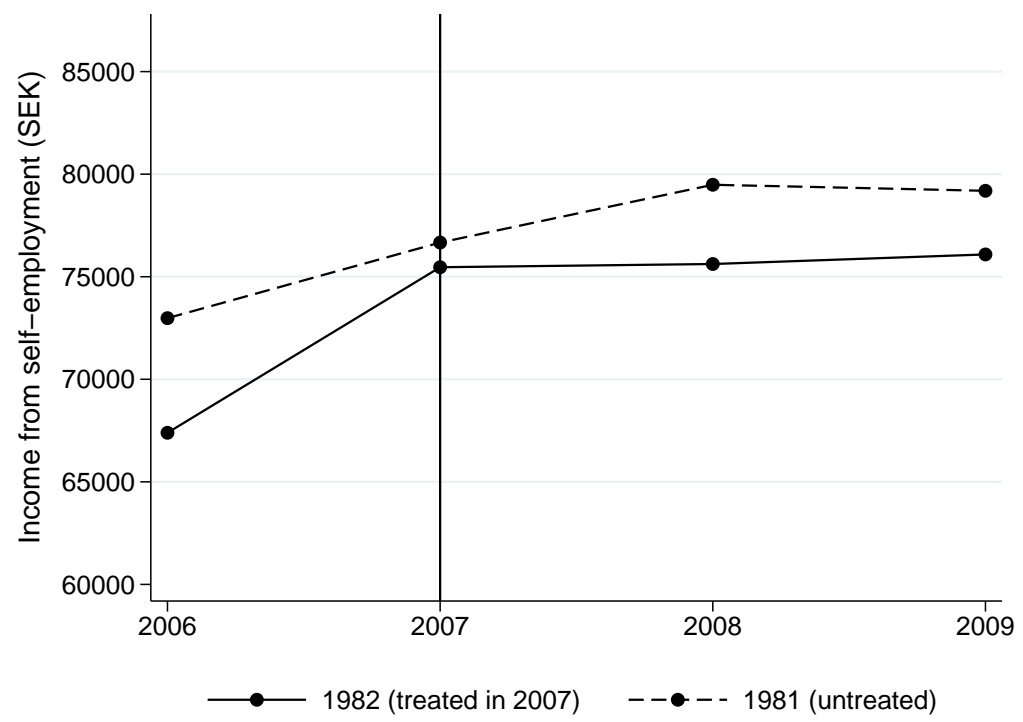


Table 8: Income effects for those self-employed in 2006

\begin{tabular}{|c|c|c|c|c|c|c|}
\hline & \multicolumn{3}{|c|}{ Income from self-employment (SEK) } & \multicolumn{3}{|c|}{ Income from wage employment (SEK) } \\
\hline & $\begin{array}{c}\text { TG: } 25 \\
\text { (1) }\end{array}$ & $\begin{array}{c}\text { TG: } 23-25 \\
(2)\end{array}$ & $\begin{array}{c}\text { TG: } 21-25 \\
(3)\end{array}$ & $\begin{array}{c}\text { TG: } 25 \\
(4)\end{array}$ & $\begin{array}{c}\text { TG: } 23-25 \\
(5)\end{array}$ & $\begin{array}{c}\text { TG: } 21-25 \\
(6)\end{array}$ \\
\hline DD 07-09 & $\begin{array}{c}18,840^{* * *} \\
(4,750)\end{array}$ & $\begin{array}{c}17,720^{* * *} \\
(3,980)\end{array}$ & $\begin{array}{c}14,680^{* * *} \\
(3,730)\end{array}$ & $\begin{array}{c}-4,229 * * \\
(2,230)\end{array}$ & $\begin{array}{c}-6,190 * * * \\
(1,620)\end{array}$ & $\begin{array}{c}-6,760 * * * \\
(1,510)\end{array}$ \\
\hline $\bar{y}_{\mathrm{TG}}$ & 110,630 & 107,060 & 103,450 & 44,190 & 41,180 & 39,790 \\
\hline$N$ & 43,177 & 56,779 & 64,159 & 43,177 & 56,779 & 64,159 \\
\hline$R^{2}$ & 0.02 & 0.02 & 0.02 & 0.04 & 0.04 & 0.037 \\
\hline Effect size: & $21 \%$ & $20 \%$ & $17 \%$ & $9 \%$ & $13 \%$ & $15 \%$ \\
\hline
\end{tabular}

Notes: ${ }^{* * *} p<1 \%,{ }^{* *} p<5 \%,{ }^{*} p<10 \%$. The outcome is yearly income from self-employment in SEK. $\bar{y}_{\mathrm{TG}}$ gives the treatment group average (in SEK) in the treatment period. Years 2002-06 constitute the reference period. While the definition of the treatment group (TG) varies, the control group consists of 28-29 yearolds. Fixed effects included for year, age and demographic characteristics (see section 6). Robust standard errors in parenthesis.

In principle, we may worry about endogeneity when studying income from self-employment above. If the tax cuts affected self-employment, it is not the same types of individuals that are self-employed after 2006, and, hence, there is a selection issue that potentially could bias the income measures. ${ }^{16}$ Of course, since we saw rather convincing evidence above that nothing happened to self-employment this should not be a big concern. I nevertheless repeat the table 6 analysis for a smaller sample that keeps only those individuals who were self-employed in 2006 (i.e., one year before the reform). Columns 1-3 of table 8 are reassuring, as they show that there are significant and large income effects for the restricted sample as well.

A second advantage with using the restricted sample is that it allows me to look at income from wage employment. A large fraction (roughly one third in 2006) of the young self-employed has in fact wage income, even though it is in general low. Any effects on this margin would suggest that the tax cuts caused the self-employed to allocate time in regular wage work differently. Table 8 shows significant negative effects on income from wage employment. This means that the number

\footnotetext{
${ }^{16}$ Since it is not obvious what the selection looks like-it could be more, or less, able individuals that become self-employed - it is difficult to say in what direction the bias goes.
} 
of hours spent in regular work has (most likely) decreased. Consider, for example, 23-25 year-olds in columns 2 and 5 of table 8 (for 23-25 year-olds, the percentage effects are somewhere between the percentage effects for the other two age groups). 23-25 year-olds earn around SEK 125 per hour in regular work, implying that time in wage employment has decreased by about 50 hours per year (SEK 6,190 divided by SEK 125). Furthermore, the average yearly mechanical effect, for 23-25 yearolds in 2007-09, amounts to SEK 13,340, which means that the behavioral adjustment corresponds to SEK 4,380 per year (SEK 17,720-13,340). If we assume that a self-employed individual earns around 60 percent of the market wage (i.e., SEK 80), time in self-employment has increased by more or less the same number of hours (SEK 4,380 divided by SEK 80). ${ }^{17}$ Strikingly, based on these simple calculations it appears as if the self-employed did not increase total number of working hours in the wake of the tax reform.

While the results in table 8 suggest that self-employed individuals reallocated time from employment to self-employment, we cannot be certain that such substitution took place. It could also be that individuals just lowered their time in regular work, without increasing time as self-employed. In particular, since they suddenly have more money in the pocket they may have used the money to buy leisure by reducing time in regular work. But then the difference in the estimated and the mechanical effects in figure 7 still needs to be explained. While there are other potential reasons, for example decreasing tax evasion, it seems reasonable to interpret the results as evidence for reallocation of working hours across occupations.

I finally test for heterogeneity by using different subsamples in table A.6 in the appendix. We first conclude that there are no gender differences, as both men and women display the same percentage income increase (about 20 percent). For natives, on the other hand, the response seems to have been larger than in general (about 24 percent). The heterogeneity could be taken as support for the awareness story discussed above: since natives have higher expected knowledge about changes in the Swedish tax schedule, we expect them to respond stronger. For foreign-born the coefficient is close

\footnotetext{
${ }^{17}$ In absence of a treatment effect, average income from self-employment, for 23-25 year-olds in 2007-09, is SEK $107,060-17,720=$ SEK 89,340 (see column 2 of table 8 ). The average yearly mechanical effect is 15 percent in 2007-09, which corresponds to SEK 13,341 (15 percent of SEK 89,340 is SEK). Finally, the difference between the mechanical effect and the estimated effect, which corresponds to the yearly behavioral adjustment, is SEK 17,720-13,341=SEK 4379. Statistics Sweden assumes that a self-employed individual earns about 60 percent of the regular wage when they define self-employment; I use this assumption as guidance.
} 
to zero, and insignificant. This may appear strange at first glance, as we expect at least a mechanical effect. However, for this small sample, the comparison groups display different trends before 2007, making it difficult to identify any effects. Table A.6 also shows that those with high-income parents seem to have responded slightly less.

\section{Conclusion}

In this paper I examine the link between taxes and youth self-employment. I make use of a Swedish reform, implemented in 2007-09, which suddenly made the payroll tax and the self-employment tax vary by age. The results, based on DiD estimations, suggest that youth self-employment is insensitive to tax changes. Both a 2007 cut and a 2009 cut left self-employment completely unaffected. The lack of treatment effects is precisely estimated and is robust to a battery of sensitivity tests. The fact that there was no effect in 2009-10, i.e. in the midst of recession, suggests that (large) tax cuts have no role to play even in times of economic slowdowns. I also study intensive margin responses. I first show that for the young self-employed, that faced the lower tax rate, income from self-employment increases by up to 20 percent on average. I then compare the estimated income effect to the predicted mechanical effect (due to the lower tax rate) and find that, in each year 2007-09, the estimated effect is greater. I argue that a potential explanation for this pattern is that the tax cut caused self-employed individuals to allocate more time to self-employment - either by reducing time in leisure or in wage employment. I find some support for the reallocation of time explanation: for those that are defined as self-employed, income from employment decreases due to the tax cut. Since the income effect is temporary, however, I conclude that the (potential) reallocation of working hours did not pertain to years when an individual no longer faces the lower tax rate. The finding of adjustments of working hours is in line with recent work showing significant intensive margin responses to tax changes. 


\section{References}

Angrist, J. D. and J.-S. Pischke (2009). Mostly Harmless Econometrics. Princeton University Press.

Bennmarker, H., E. Mellander, and B. Öckert (2009). Do regional payroll tax reductions boost employment? Labour Economics 16(5), 480-489.

Blanchflower, D. and B. Meyer (1994). A longitudinal analysis of the young self-employed in australia and the united states. Small Business Economics 6(1), 1-19.

Blundell, R., M. C. Dias, C. Meghir, and J. van Reenen (2004). Evaluating the employment impact of a mandatory job search program. Journal of the European Economic Association 2(4), 569606.

Bruce, D. (2000). Effects of the united states tax system on transitions into self-employment. Labour Economics 7(5), $545-574$.

Bruce, D. (2002). Taxes and entrepreneurial endurance: Evidence from the self-employed. National Tax Journal 55(1), pp. 5-24.

Cahuc, P., S. Carcillo, and T. Le Barbanchon (2014). Do Hiring Credits Work in Recessions? Evidence from France. IZA Discussion Papers 8330, Institute for the Study of Labor (IZA).

Chetty, R., J. N. Friedman, and E. Saez (2013). Using differences in knowledge across neighborhoods to uncover the impacts of the eitc on earnings. American Economic Review 103(7), 2683-2721.

Chetty, R., A. Looney, and K. Kroft (2009). Salience and taxation: Theory and evidence. American Economic Review 99(4), 1145-77.

Cullen, J. B. and R. H. Gordon (2004). Taxes and entrepreneurial activity: Theory and evidence for the us. NBER Working Paper 9015, NBER Cambridge.

Domar, E. D. and R. A. Musgrave (1944). Proportional income taxation and risk-taking. The Quarterly Journal of Economics 58(3), 388-422. 
Dunn, T. and D. Holtz-Eakin (2000). Financial capital, human capital, and the transition to self employment: Evidence from intergenerational links. Journal of Labor Economics 18(2), pp. $282-305$.

Edmark, K., C.-Y. Liang, E. Mörk, and H. Selin (2012). Evaluation of the swedish earned income tax credit. Working Paper Series 2012:1, IFAU - Institute for Evaluation of Labour Market and Education Policy.

Egebark, J. and N. Kaunitz (2013). Do payroll tax cuts raise youth employment? Working Paper Series 2013:27, IFAU - Institute for Evaluation of Labour Market and Education Policy.

European Comission (2013). Youth Employment Package. European Comission, Brussels.

Ferran, E. (2015). Labor demand elasticities over the life cycle: Evidence from spain's payroll tax reforms. Job market paper, Columbia University.

Gentry, W. M. and G. Hubbard (2003). Tax policy and entry into entrepreneurship. mimeograph, Columbia University.

Gentry, W. M. and G. Hubbard (2004). Success taxes, entrepreneurial entry, and innovation. NBER Working Paper 10551, NBER Cambridge.

Gruber, J. (1997). The incidence of payroll taxation: Evidence from chile. Journal of Labor Economics 15(3), S72-101.

Hansson, A. (2012). Tax policy and entrepreneurship: empirical evidence from sweden. Small Business Economics 38(4), 495-513.

Huttunen, K., J. Pirttilä, and R. Uusitalo (2013). The employment effects of low-wage subsidies. Journal of Public Economics 97(0), $49-60$.

OECD (2012). Policy Brief on Youth Entrepreneurship: Entrepreneurial Activities in Europe. Technical report, OECD, Paris. 
OECD (2013). Self-employment among the youth and seniors: Entrepreneurship at a Glance 2013. Technical report, OECD, Paris.

Oosterbeek, H., M. van Praag, and A. Ijsselstein (2010). The impact of entrepreneurship education on entrepreneurship skills and motivation. European Economic Review 54(3), 442 - 454.

Schuetze, H. J. (2000). Taxes, economic conditions and recent trends in male self-employment: a canada us comparison. Labour Economics 7(5), 507 - 544.

Skedinger, P. (2012). Tudelad trygghet. In A. Teodorescu and L.-O. Pettersson (Eds.), Jobben kommer och går : behovet av trygghet består, pp. 114-135. Stockholm: Ekerlid.

Skedinger, P. (2014). Effects of Payroll Tax Cuts for Young Workers. Nordic Economic Policy Review (forthcoming).

Stabile, M. (2004). Payroll taxes and the decision to be self-employed. International Tax and Public Finance 11(1), 31-53.

Statistics Sweden (2014). Arbetskraftundersökningarna. SCB, Stockholm. 


\section{A Appendix}

\section{A.1 Additional extensive margin results}

Table A.1: Pooled treatment effects, using 27-year-olds as control group

\begin{tabular}{lccccc}
\hline & \multicolumn{2}{c}{ FULL SAMPLE } & & \multicolumn{2}{c}{ CONDITIONAL } \\
\cline { 2 - 3 } \cline { 5 - 6 } & TG: 25 & TG: $21-25$ & & TG: 25 & TG: $21-25$ \\
\hline \multirow{2}{*}{ DD 07-08 } & 0.022 & -0.0004 & & 0.033 & -0.022 \\
& $(0.062)$ & $(0.049)$ & & $(0.071)$ & $(0.056)$ \\
& & & & \\
\hline $\bar{y}_{\text {TG }}$ & 2.2 & 1.5 & & & \\
$N$ & $1,093,515$ & $3,257,921$ & & 914,908 & $3,170,954$ \\
$R^{2}$ & 0.004 & 0.005 & & 0.004 & 0.006 \\
\hline \multicolumn{3}{r}{ Notes: $^{* * *} p<1 \%, * * p<5 \%,{ }^{*} p<10 \%$. See also notes for table 3.}
\end{tabular}

Table A.2: Yearly treatment effects, using 27-year-olds as control group

\begin{tabular}{|c|c|c|c|c|}
\hline & \multicolumn{2}{|c|}{ FULL SAMPLE } & \multicolumn{2}{|c|}{ CONDITIONAL } \\
\hline & TG: 25 & TG: $21-25$ & TG: 25 & TG: $21-25$ \\
\hline DD 2006 & $\begin{array}{l}-0.005 \\
(0.082)\end{array}$ & $\begin{array}{c}0.012 \\
(0.066)\end{array}$ & $\begin{array}{l}-0.051 \\
(0.095)\end{array}$ & $\begin{array}{l}-0.083 \\
(0.076)\end{array}$ \\
\hline DD 2007 & $\begin{array}{c}0.086 \\
(0.082)\end{array}$ & $\begin{array}{c}0.061 \\
(0.065)\end{array}$ & $\begin{array}{c}0.11 \\
(0.095)\end{array}$ & $\begin{array}{c}0.021 \\
(0.074)\end{array}$ \\
\hline DD 2008 & $\begin{array}{l}-0.056 \\
(0.083)\end{array}$ & $\begin{array}{l}-0.054 \\
(0.067)\end{array}$ & $\begin{array}{l}-0.081 \\
(0.096)\end{array}$ & $\begin{array}{c}-0.12 \\
(0.076)\end{array}$ \\
\hline $\bar{y}_{\mathrm{TG}}$ & 2.2 & 1.5 & 2.5 & 1.7 \\
\hline$N$ & $1,093,515$ & $3,257,921$ & 914,908 & $2,714,310$ \\
\hline$R^{2}$ & 0.004 & 0.005 & 0.004 & 0.006 \\
\hline
\end{tabular}


Table A.3: Pooled treatment effects, using different definition of self-employment

\begin{tabular}{|c|c|c|c|c|}
\hline & \multicolumn{2}{|c|}{ FULL SAMPLE } & \multicolumn{2}{|c|}{ CONDITIONAL } \\
\hline & TG: 25 & TG: $21-25$ & TG: 25 & TG: $21-25$ \\
\hline DD 07-08 & $\begin{array}{l}0.0004 \\
(0.070)\end{array}$ & $\begin{array}{l}-0.026 \\
(0.041)\end{array}$ & $\begin{array}{l}-0.002 \\
0.08175\end{array}$ & $\begin{array}{l}-0.077 \\
(0.048)\end{array}$ \\
\hline $\bar{y}_{\mathrm{TG}}$ & 3.1 & 2.2 & 3.4 & 2.5 \\
\hline$N$ & $1,091,071$ & $3,804,593$ & 909,945 & $3,170,954$ \\
\hline$R^{2}$ & 0.004 & 0.006 & 0.004 & 0.007 \\
\hline
\end{tabular}


Table A.4: Treatment effects by own and parents' characteristics

Panel A: Own characteristics

Full sample, $21-25$ vs. $26-27$

\begin{tabular}{lcccccc} 
& Men & Women & Natives & F-born & Voc/broad & Voc/narrow \\
\cline { 2 - 7 } DD 07-09 & & & & & & \\
& -0.0047 & -0.015 & -0.012 & -0.090 & -0.142 & -0.087 \\
& $(0.057)$ & $(0.041)$ & $(0.039)$ & $(0.080)$ & $(0.080)$ & $(0.151)$ \\
$\bar{y}_{\text {TG }}$ & & & & & & \\
$N$ & 1.9 & 1.1 & 1.6 & 1.6 & 2.0 & 1.6 \\
$R^{2}$ & $1,943,792$ & $1,860,801$ & $3,168,643$ & 635,950 & $1,04,631$ & 291,316 \\
& 0.004 & 0.002 & 0.005 & 0.003 & 0.005 & 0.006
\end{tabular}

Panel A: Parents' characteristics

Full sample, $21-25$ vs. $26-27$

Conditional, $21-25$ vs. $26-27$

\begin{tabular}{ccccccc}
\hline Self-empl. & Inc. $>\mathrm{Md}$ & Top qt inc. & & Self-empl. & Inc. $>\mathrm{Md}$ & Top qt inc. \\
\hline & & & & & & \\
0.027 & -0.019 & -0.030 & & -0.019 & -0.041 & -0.060 \\
$(0.133)$ & $(0.041)$ & $(0.049)$ & & $(0.143)$ & $(0.048)$ & $(0.061)$ \\
& & & & & \\
\hline 3.4 & 1.3 & 1.3 & & 3.5 & 1.4 & 1.5 \\
556,753 & $2,474,792$ & $1,637,961$ & & 501,506 & $2,046,101$ & $1,284,848$ \\
0.19 & 0.13 & 0.13 & & 0.20 & 0.13 & 0.14
\end{tabular}

Notes: ${ }^{* *} p<1 \%,{ }^{* *} p<5 \%,{ }^{*} p<10 \%$. Voc/broad includes all individuals with vocational training.

Voc/narrow consists of construction workers. See also notes for table 6 . 


\section{A.2 Additional intensive margin results}

Table A.5: Yearly treatment effects, 2005-2009. Cluster robust standard errors

\begin{tabular}{|c|c|c|c|c|}
\hline & \multicolumn{4}{|c|}{ Income from self-employment (SEK) } \\
\hline & TG: 25 & TG: $23-25$ & TG: $21-25$ & TG: 26 \\
\hline \multirow[t]{3}{*}{ DD 2005} & 1,720 & 290 & 890 & $-1,740$ \\
\hline & $(990)$ & $(1,610)$ & $(1,700)$ & $(1,380)$ \\
\hline & {$[640]$} & {$[680]$} & {$[840]$} & {$[1,190]$} \\
\hline \multirow[t]{3}{*}{ DD 2006} & -370 & 63 & 910 & 760 \\
\hline & $(1,340)$ & $(1,640)$ & $(1,760)$ & $(1,640)$ \\
\hline & {$[650]$} & {$[680]$} & {$[840]$} & {$[1,180]$} \\
\hline \multirow[t]{3}{*}{ DD 2007} & $3,065^{* * *}$ & $5,390 * * *$ & $8,130 * * *$ & $-1,095$ \\
\hline & $(960)$ & $(1,480)$ & $(1,930)$ & $(2,670)$ \\
\hline & {$[640]$} & {$[670]$} & {$[830]$} & {$[1,180]$} \\
\hline \multirow[t]{3}{*}{ DD 2008} & $9,730 * * *$ & $13,150 * * *$ & $13,060 * * *$ & 1,840 \\
\hline & $(820)$ & $(1,600)$ & $(2,000)$ & $(1,260)$ \\
\hline & {$[650]$} & {$[680]$} & {$[840]$} & {$[1,190]$} \\
\hline \multirow[t]{2}{*}{ DD 2009} & $\begin{array}{c}16,600 * * * \\
(1,850)\end{array}$ & $\begin{array}{c}17,240 * * * \\
(1,970)\end{array}$ & $\begin{array}{c}17,930^{* * *} \\
(1,990)\end{array}$ & $\begin{array}{c}13,300^{* * *} \\
(2,089)\end{array}$ \\
\hline & {$[650]$} & {$[680]$} & {$[850]$} & {$[1,190]$} \\
\hline $\bar{y}_{\mathrm{TG}}$ & 81,350 & 79,730 & 76,990 & 85,120 \\
\hline$N$ & 103,522 & 140,350 & 162,721 & 107,802 \\
\hline$R^{2}$ & 0.018 & 0.017 & 0.018 & 0.018 \\
\hline No. of clusters & (24) $[16]$ & (40) $[16]$ & (56) $[16]$ & (24) $[16]$ \\
\hline
\end{tabular}


Table A.6: Income effects by own and parents' characteristics

Full sample, 21-25 vs. 28-29

\begin{tabular}{|c|c|c|c|c|c|c|c|}
\hline & \multicolumn{4}{|c|}{ Own characteristics } & \multicolumn{3}{|c|}{ Parents' characteristics } \\
\hline & Men & Women & Natives & F-born & Self-empl. & Inc. $>\mathrm{Md}$ & Top qt inc. \\
\hline DD 07-09 & $\begin{array}{c}12,910^{* * *} \\
(1,600)\end{array}$ & $\begin{array}{c}11,217^{* * *} \\
(1,870)\end{array}$ & $\begin{array}{c}15,305^{* * *} \\
(1,360)\end{array}$ & $\begin{array}{c}-217 \\
(2,910)\end{array}$ & $\begin{array}{c}13,590^{* * *} \\
(2,510)\end{array}$ & $\begin{array}{c}12,700^{* * *} \\
(1,530)\end{array}$ & $\begin{array}{c}11,900^{* * *} \\
(1,860)\end{array}$ \\
\hline $\bar{y}_{\mathrm{TG}}$ & 79,460 & 72,300 & 79,000 & 67,330 & 78,790 & 77,540 & 73,063 \\
\hline$N$ & 108,384 & 54,337 & 137,847 & 24,874 & 42,051 & 93,764 & 64,103 \\
\hline$R^{2}$ & 0.02 & 0.01 & 0.02 & 0.02 & 0.02 & 0.02 & 0.02 \\
\hline Effect size: & $19 \%$ & $18 \%$ & $24 \%$ & - & $21 \%$ & $20 \%$ & $19 \%$ \\
\hline
\end{tabular}




\section{Publication series published by IFAU - latest issues}

\section{Rapporter/Reports}

2016:1 Engdahl Mattias and Anders Forslund "En förlorad generation? Om ungas etablering på arbetsmarknaden"

2016:2 Bastani Spencer, Ylva Moberg and Håkan Selin "Hur känslig är gifta kvinnors sysselsättning för förändringar i skatte- och bidragssystemet?"

2016:3 Lundin Martin, Oskar Nordström Skans and Pär Zetterberg "Kåren och karriären: Studentpolitiken som språngbräda"

2016:4 Brommesson Douglas, Gissur Erlingsson, Johan Karlsson Schaffer, Jörgen Ödalen and Mattias Fogelgren "Att möta den högre utbildningens utmaningar"

2016:5 Egebark Johan "Effekter av skatter på ungas egenföretagande"

\section{Working papers}

2015:23 Mellander Erik and Joakim Svärdh "Inquiry-based learning put to test: long-term effects of the Swedish science and technology for children program"

2015:24 Norén Anna "Childcare and the division of parental leave"

2015:25 Åslund Olof, Ina Blind and Matz Dahlberg "All aboard? Commuter train access and labor market outcomes"

2015:26 Fredriksson Peter, Lena Hensvik and Oskar Nordström Skans "Mismatch of talent: evidence on match quality, entry wages, and job mobility"

2015:27 Fredriksson Peter, Hessel Oosterbeek and Björn Öckert "Parental responses to public investments in children: evidence from a maximum class size rule"

2015:28 Hensvik Lena and Olof Rosenqvist "The strength of the weakest link: sickness absence, internal substitutability and worker-firm matching"

2015:29 Johansson Per, Lisa Laun and Mårten Palme "Health, work capacity and retirement in Sweden"

2016:1 Bastani Spencer, Ylva Moberg and Håkan Selin "Estimating participation responses using transfer program reform"

2016:2 Lundin Martin, Oskar Nordström Skans and Pär Zetterberg "Leadership experiences, labor market entry,and early career trajectories"

2016:3 van den Berg Gerard J., Lena Janys, Enno Mammen, Jens P. Nielsen "A general semiparametric approach to inference with marker-dependent hazard rate models"

2016:4 Egebark Johan "Effects of taxes on youth self-employment and income"

\section{Dissertation series}

2015:1 Egebark Johan "Taxes, nudges and conformity. Essays in labor and behavioral economics"

2015:2 Blind Ina "Essays on urban economics" 